\title{
EVOLVING DIMENSIONS OF SECURITY AND ITS RELEVANCE IN NEPAL
}

\author{
Aswasthama Bhakta Kharel, PhD*
}

\begin{abstract}
"Security" has been defined in different ways by different political scientists, economists, researchers and authors according to the change in course of time and the emergence of the feel of its necessity in various fields. Security includes absence or resilience against potential damage or harm, presence of essential goods, containment and feel of being secured and protected. The evolving dimensions of security concerns about the protection of people not only against war and several forms of unstructured violence but also against hunger, diseases, terrorism, environmental degradation and other global issues. This sketches the globalization of security concept dealing with the state-security and the human security. Numbers of new and challenging security issues are being observed as the world has entered into the economy and power competition among different countries and allies of the countries. This demands for the implication of reformed and effective security strategies. Whereas, Nepal being a South Asian country and a country that is just transitioning from a decade long insurgency and political instabilities, has been facing numerous security matters in national and international levels that are required to be resolved through fruitful initiatives and practical approaches. There is a need of comprehensive and co-ordinate approach to reform the security sectors of Nepal for overall peace and prosperity in the country. The research here is done for the same on the basis of documentary analysis of different journals, public documents, reports, articles, books and research papers from which factual data are included.
\end{abstract}

Keywords: Security Policy, Security Forces, Delivery Systems, State Security, Issues

\section{Introduction}

Security is the condition of being free from any kind of danger or harm. Security has been a deep context and a major concern for many states in the world. As terror, torture, destructions, wars and conflict are increasing in different ways and forms; the challenge has been faced for the attainment of security including national and human security for every countries of the world. In philosophy, security was originally concerned to the protection of individual human. After the Second World War, the security concept got broadened and extended. New conceptualizations of security such as societal security, human security, international security, and homeland security emerged (Rothschild, 1995, p. 65). Security is the pursuit of freedom from threat and the ability of states and societies to maintain their independent identity and their functional integrity against forces of change, which they see as hostile (Buzan, 1983, p. 5-7). Assistant Professor of Central Department of Politial Science (Faculty of Humanities and Social Sciences), Tribhuvan
University, Nepal 
The new world order that emerged from the dying embers of the World Wars completely changed the outlook of states and people. States that have since then been concerned about their respective sovereignty and development now look towards framing policies and thoughts that align with the tenets of human development and security (Karki, 2020, p. 1). Security concept is broadening as per the increment of transforming security threats in the world. It is conceptually interdependent, methodologically complex and strategically fundamental to secure nation's social, economic and political interests against the threats arising from other states (Huntington, 1985, pp. 3-9). In the conventional notion, security was explained in the frame of national security to be provided by the security forces, mainly military, using different strategies and activities that minimize or neutralize the efforts of external actors but the modern concept of security goes beyond conventional scope and deals with societal, human and environmental security issues (Upreti and Vanhautte, 2009, pp. 174-177). Modern concept of security concerns about the issues of human rights, economics, environmental components, epidemics, crime, drugs trafficking or any kind of social injustice, in addition to the traditional concern with prevention from external military threats. The decrease in vulnerability is security (Ullman, 1983, pp. 137-139). It is the capability of country to protect its core values, both in terms that a state need not sacrifice the core values in avoiding war and can maintain them by winning war (Lippmann, 1944, pp. 599-601). In the context of Nepal, fundamental values, norms, and national interests are very important (Bhushal, 2076 BS, p. 22). For long, Nepal's security sector faced institutional and governance bottleneck (Upreti, 2019, p. 3). Economic issues grew more salient in the late 1960s and were increasingly treated as important political and broader architectural elements of both national security and the larger security order (Sperling \& Kirchner, 1995, p.1). But it has changed the situation in the world security dimensions nowadays.

\section{Dimensions of Security}

Security is a multi-dimensional concept which can be broadly classified into five major dimensions such as human security, environmental security, national security, transnational security, trans-cultural security. The twentieth century was dominated by the legacy of devastating world wars, independence movements, colonial struggles and ideological conflicts so that those wars and conflicts seriously undermined the fundamental principle of people's political security and the peace and harmony of society (Wagle, 2013, p.254). Global security can only be achieved through good governance of countries with the provision of equal justice for all individuals, states and cultures.

\section{Human Security:}

Human security is an approach of states in identifying and addressing widespread and crosscutting challenges to the survival, livelihood and dignity of the people. It calls for peoplecentered, comprehensive, context specific and prevention-oriented responses that strengthen the protection and empowerment of all people (UN, 2012). Human security is a major dimension of the security as it is the security of people and communities, as opposed to the security of states. Sustainable peace is advocated by human security through the recognition of social, political and economic grievances that are often the main causes of conflict and societal violence. Scope of the human security to includes are economic, food, health, environmental, personal, community and 
political security (Singh, 2019, p.61). The basic concept of human security reflects a number of developments that have incrementally challenged the traditional view of security as the protection of states (Singh, 2019, p.66). Human security safeguards and expands people's vital freedoms. It concerns in protecting people from critical and pervasive threats thus empowering them to take charge of their own lives.

\section{Environmental Security:}

Environmental security is the proactive minimization of anthropogenic threats to the functional integrity of the biosphere and thus to its interdependent human component (Barnett, 2001, pp. 1418). It is the relative public safety from environmental dangers caused by natural or human processes due to ignorance, accident, mismanagement or design and originating within or across national borders. Environmental security concerns about the adverse impact of human activities on the environment and the direct and indirect effects of various forms of environmental change which may be natural or human-generated on national and regional security. It also concerns about the insecurity individuals and groups experience due to environmental change such as pollution, water scarcity, global warming, and so on. Therefore, environmental security is the condition in which social systems interact with ecological systems in sustainable ways, all individuals have fair and reasonable access to environmental goods, and mechanisms exist to address environmental crisis and conflict (TMP, 2020).

\section{National Security:}

National security is the protection of the survivability of a state through the exercise of economic power, power projection, intelligence agencies, political power and diplomacy. National security then is the ability to preserve the state's physical integrity and territory; to maintain its economic relations with the rest of the world on reasonable terms; to preserve its nature, institution, and governance from disruption from outside and to control its borders. Its distinctive meaning is freedom from foreign dictation (Lasswell, 1950, p. 2). National Security is associated primarily with managing physical threats and with the military capabilities used for doing so. It includes mobilization of military forces to guarantee the state's borders and to deter or successfully defend against physical threats including military aggression and attack by violent non-state actors.

\section{Transnational Security:}

Transnational security addresses the issues other than military threats that cross borders and threaten the political and social integrity of a state. Transnational threats include transnational crime, terrorism, nuclear proliferation, arms trafficking, illegal migration, cybercrime, maritime piracy, epidemics, energy insecurity, and so on. Transnational security concerns for a multi-lateral approach to security issues. It requires close exchange and cooperation between states and relevant non-state actors alike.

\section{Transcultural Security:}

Transcultural security is not only the protection of cultural rights of people of different origins, but it is the appreciation and conservation of beliefs, views, thoughts and opinions of people belonging to various communities. Transcultural security addresses the issues of conflict aroused from the cultural and religious differences in people belonging to different societies. 
Other dimensions of security include addressing of the global issues of energy conservation, environmental sustainability, and hunger relief, provision of health and education, and peaceful co-existence of all.

\section{Security Policy of Nepal}

The Constitution of Nepal, 2015 interprets the state's obligation towards its citizens and defines core security system of the country, intra-state security issues including peace and harmony, international security and civil-military relations. In the prospective of internal security, the territorial integrity mentioned in the constitution can be observed. Security is presented explicitly as a national interest in the constitution of Nepal. As Nepal follows the principles of nonalignment and Panchasheel, the security aspects and policies of Nepal are formed in respect to these principles. Both inter-state and intra-state security are mentioned as the national interest in article 5 of the Constitution of Nepal, 2015 as the article states "independence, sovereignty, territorial integrity, nationality, autonomy, self-respect, protection of rights and interests of Nepali people, protection of boundaries, and economic progress and prosperity, shall be the fundamental subjects of Nepal's national interest."

Nepal's long term security vision and policy is primarily based upon three major facets that are security (state, human and societal security), peace (equity, justice, human rights and dignity) and stability (political, economic and social stability). Article 51 (a) of the Constitution of Nepal, 2015 presents the account of state's policy on national unity and national security. It includes the provision of maintaining law and order by developing a national security system; making all the security organs, including Nepali Army, Nepal Police and Armed Police Force competent, strong, professional, inclusive and accountable to the people on the basis of national security policies. The constitution has set provisions for four security bodies in Nepal- Nepali Army, Nepal Police, Armed Police Force and National Investigation Department. Nepali Army safeguards independence, sovereignty, territorial integrity and national unity of the country whereas other security bodies also function for the progress of the state through maintenance of rule of the law, good governance and peaceful co-existence among people of the state. Human security issues are also addressed through provisions of social justice and social security as fundamental rights reflected in state's guiding principles and policies of the Constitution of Nepal, 2015. For addressing both conventional and modern security challenges, article 266 of the constitution has provisioned a National Security Council chaired by Prime-minister to make recommendation to the Council of Ministers, Government of Nepal for the formulation of policy on overall national interest; security and defense of Nepal, and for the mobilization of the Nepali Army. Information are obtained from relevant security agencies for formulation of national security policy, shortterm, mid-term and long-term national security strategy and action plan by National Security Council of Nepal. Also, the council suggests the government to use defense diplomacy for safeguarding national interest and strengthening the security of Nepal, develops action plan for modernization of Nepali Army, formulates policy related to weapons and logistics required for security agencies, and conducts study and research on national security and defense.

National Security Policy, 2016 stresses on improving and strengthening counter intelligence capacity of national intelligence agency of Nepal. The policy tends to address the dimensions of politics, economy, social security, natural resources, diplomacy, environment, energy, culture, 
information and technology, public and private value systems, climate change, natural disasters, property, national pride and human rights in Nepal. National Security Policy has presented the solution measures for various security challenges faced by Nepal in national and international arena by focusing on civil protection, human rights promotion, economic progress, power decentralization, protection of national assets, poverty alleviation, cultural and communal unity, preservation of national heritages and controlling every kinds of terrorism, war or conflict situation in the country.

\section{Security Service Delivery System in Nepal}

Constitution of Nepal, 2015 has maintained the provisions regarding national security in part 28 , article 266-268 mentioning the formation, structure and role of different security bodies in Nepal. Security services in Nepal are delivered by Nepali Army, Nepal Police, Armed Police Force and National Investigation Department on the basis of security policies drafted by National Security Council.

\section{Ministry of Defense:}

The ministry of defense is a governmental body in Nepal that formulates defense policies and coordinates defense affairs with other agencies of the government and the Nepal Army. Defense ministry was formally set up for the first time in 1950 by the then interim government headed by Prime-minister Mohan Shumsher. Babar Shumsher was made the first defense minister. The establishment of ministry of Defense was done in order to protect and defend the country and its people from internal instability and external threats by ensuring the sovereignty, national independence and integrity of the country. Ministry of Defense primarily functions in managing and operating national defense affairs. The ministry is responsible for maintaining internal as well as external security in order to safeguard the national sovereignty and territorial integrity. It is also responsible for maintaining internal law and order by protecting the lives and properties of the people. Defense ministry principally focuses to make policy directions on defense and security matters and communicate them for implementation to the Nepali Army and its various service departments (MoD, 2020). Ministry of Defense according to business (allocation) regulation 2063 , is responsible for the functions such as organization and control of the Nepalese Army, coordination of military training, oversight of military welfare procurement and production of military hardware, oversight of military activities and military operation, oversight and coordination of military construction, development of military academy, instillation, communication and transport, provision of military storage, enhancement of military intelligence capabilities, development and establishment of military hospitals, establishment and management of military barracks and offices, coordination and direction of military assistance in natural calamities and development, organization, training and administration of the national cadet corps, welfare of retired military personnel, oversight, establishment and coordination of national parks and wildlife reserves, provision and procurement of military aircraft, welfare schemes, coordination with national security council and so on. Ministry of Defense forms the organization and operation of military forces of the country. 


\section{National Security Council:}

The constitutional provision relating to National Security in article 266 of part 28 of the Constitution of Nepal, 2015 states that there shall be a National Security Council for making recommendation to the government of Nepal, Council of Ministers for the formulation of policies on national interest, security and defense and to control or operate Nepal Army. National Security Council comprises of Defense minister, Home minister, minister of Foreign Affairs, Finance minister, chief secretary of Government of Nepal and chief of the Army staff as members, chaired by the Prime-minister of the country. The secretary of ministry of Defense works as the secretary of the Council. Security policies are formed, revised and updated by National Security Council according to the changing political context recommending to the Council of Ministers, Government of Nepal. The council can also seek necessary suggestions, details and information from any of the security bodies along with the bodies of the Nepal Government that it deems necessary for national welfare, security and defense.

\section{Nepali Army:}

Nepali Army is the military land warfare force of Nepal formerly known as the "Gurkha Army" during the unification of Nepal and later as "The Royal Nepalese Army" during the monarchy period in Nepal. The National Army got renamed from "Royal Nepalese Army" to Nepalese Army after monarchy was abolished and the country became republic on 28 may 2008. Article 267 of the Constitution of Nepal, 2015 has mentioned the provision relating to Nepal Army stating that there shall be an organization of Nepali Army committed to democratic principles, inclusive in character and national in form, for the protection of Nepal's independence, sovereignty, territorial integrity, autonomy, and national unity. The president is the Supreme Commander- in -Chief of the Nepal Army. The Government of Nepal, in accordance with federal law, mobilizer Nepal Army for works relating to development, disaster management and others. Mobilization of Nepal Army is declared by the president according to the decision by Council of Ministers, Government of Nepal on recommendation of National Security Council during wars on security of any parts, territorial integrity or sovereignty of Nepal, external attacks and armed insurgency or serious crisis arisen due to extreme economic breakdown. Nepali Army took part in wars like Gurkha-Sikh War, Sino-Nepalese War, Nepalese - Tibetan War, Anglo-Nepalese War, World Wars, Somali Civil War, Sierra Leone Civil War, Eritrean- Ethiopian War, Second Sudanese Civil War, Nepalese Civil War, Syrian Civil War and others. Nepali Army has also been utilizing its trained manpower and resources in support of national progress for many decades. Nepali Army is engaged in infrastructural development of the country through developing road networks in remote and rugged areas of Nepal. Nepali Army has been responsible for the conservation of nature forwhich 12 out of the 22 protected forests in Nepal is being protected by Nepali Army. Comprehensive nationwide rehabilitation programs are being launched in the country through establishment of National Rehabilitation Centre by Nepali Army with the help of Government of Nepal that provides physical, psychological and vocational rehabilitation as well as social awareness program mainly to the victims of wars of conflict. On the role of disaster management, Nepal Army has historically provided vital relief during floods, earthquake ,avalanches, fires landslides, air and other transportation disasters in Nepal through search and rescue missions, medical assistance and evacuation, mass evacuation and so on 
(Nepali Army, 2020). About 95000 active Army Personnel are recently working in Nepali Army (The Himalayan, 2020).

\section{Armed Police Force, Nepal:}

The Armed Police Force of Nepal is a paramilitary land force tasked with counter insurgency operations in Nepal. It functions as a semi -military wing, and occupies a sort of dual role as both military and law enforcement. According to Article 268 of constitution of Nepal, 2015 provisions for the formation role and structure of Armed Police Force of Nepal. National border patrol, security and integrity are the specialist jurisdictions of Armed Police Force of Nepal. It was founded in $2001 \mathrm{AD}$ in Nepal fundamentally as a paramilitary organization of the country thus being engaged in counter -insurgency operations. Armed Police Force Act, 2001 includes the roles and functions of this force such as to control any ongoing or would be armed conflict armed rebellion, separatist activities, terrorist activities or riots within the country to assist in rendering relief to natural calamity or epidemic victims, to rescue any citizen or else from hostage captivity or in the event of occurrence of heinous and serious crimes or unrest of grave nature or of anticipation, to guard border of the country, to assist under the Nepali Army in condition of external invasion, to protect public vital installations, infrastructures and other facilities assigned by the Government of Nepal, to protect the personalities and public vital installations, institutes and other facilities considered to be given protection by the Government of Nepal, to perform tasks assigned from time to time by the Government of Nepal, to mobilize in customs, revenue and industrial security and many others as required by the country in various crisis situations. Armed Police Force of Nepal also contributes its soldiers in peacekeeping efforts under the coveted blue flag of the United Nations for global peace and security as a whole. Since October 2002, Armed Police Force, Nepal has made contributions to various UN Peacekeeping Missions as UN Police advisers, instructors, monitors and contingent (APF, 2020).

\section{Nepal Police:}

Nepal Police is the primary law enforcement agency of Nepal mainly responsible for maintaining law and order, prevention of crime and investigation in the country within the jurisdiction determined by the constitution of Nepal. Article 268 of the constitution of Nepal, 2015 has included the provision relating to Nepal Police regarding its operation, supervision and coordination as provided by Federal Law and Police Act 1955. Apart from its primary role, Nepal Police conducts vast array of duties such as VIP Protection, Security of vital installations, traffic management, secret services, intelligence collection, riot control, disaster management, hostage rescue and other ceremonial roles. Total of 79554 police personnel are actively working in Nepal Police. It has 2344 permanent and 507 temporary police officers and units spread all over the country. The Nepalese Police is headed by The Inspector General of Police who reports directly to Ministry of Home Affairs. Nepal Police Service for truth, service and security of its country (Nepal Police, 2020).

\section{National Investigation Department:}

As per the provision in article 268 of the Constitution of Nepal, 2015, National Investigation Department is mandated as the main intelligence agency of Nepal collecting information about country's public security, economic crimes, corruption, domesticand cross-border terrorism, 
money laundering, narcotics, and human trafficking. National Investigation Department was formed in 1962 that works under the Office of the Prime-minister and Council of Ministers. The primary role of National Investigation Department is to collect and disseminate timely and requisite credible information, analysis and recommendations to the Government of Nepal so that anything detrimental to national security for its promotion, preservation and protection of constitution will be addressed in time. As provisioned by federal law of Nepal, the tasks of National Investigation Department are running National Intelligence Service in terms of policy standard, planning, implementation and regulation; information collection on all activities against constitution, national security and national interest including armed conflict, armed underground groups, communal, racial, religious, financial, organizational crimes, illegal organizations and public interests, transnational crime and border encroachment; espionage and counter espionage; security co-ordination; capacity building; assessment on terrorism and regional security threats; verification of Nepali citizen and foreigners, VIP/VVIP security, vital installations and their security; analysis and report on national security situation and information collection , analysis and timely submission of reports of the agreements and the finding of positive or negative impacts of agreements signed between Nepal and other countries where Nepal is one of the parties. Around more than 1000 agents are affiliated with the National Investigation Department of Nepal.

\section{Security Issues}

Security issues are the challenges or threats faced while maintaining human security, state security or social security throughout the globe. Ranging from traditional state-centric security issues to new transnational security threats and to broader issues of human security, various security matters are prevalent which are needed to be solved very effectively. Terrorism and nonstate political violence, internal conflict and civil war, ethnic and self-determination conflicts, state failure and state collapse, peacekeeping, peace building and post-conflict reconstruction, arms proliferation and weapons of mass destruction, environmental and other resources related conflicts and risks, organized crime, migration, border issues and border control etc. are the various emerging security issues in the world. Security and peace in states is contingent upon security and stability in the world. With the growing interdependency in the present globalized world, the action of one state has the capacity to influence and alter the actions and policies of other states. There is an emerging class of non-military threats with the potential to challenge and destabilize domestic and global security. Insecurity in today's world is more about lack of basic amenities, rights and freedom. With the collapse of the Soviet Union, an era of new security challenges ushered in encompassing the proliferation of weapons of mass destruction, international terrorism, regional conflicts, ethnic nationalism and others (Raghavan, 2007, pp. 2833). Any future security framework must be able to tackle conventional and unconventional security challenges (Upreti, 2019, p.3).National and International Security are in the verge of being endangered due to various crimes like terrorism, serious and organized crime, trafficking in illicit drugs and arms, human trafficking, sexual exploitation of minors and pornography, economic crime, cybercrime, corruption, document fraud, money laundering and many more. 


\section{Human Security Issues:}

Human Security is an approach to national and international security that gives primacy to human beings and their complex social and economic interaction. Human security concerns safety of people from traditional (military) and non-traditional (poverty, diseases etc.) threats. Human security deprivation can undermine peace and stability within and between states. An overemphasis on state security can be detrimental to human welfare. Major issues associated with human security are economic, food, health, environmental, personal, community and political security issues. Economic security includes issues ensured basic income and employment, and access to such social safety net. Food security relates access to basic nutrition and food supply. Health security covers issues such as access to health service, access to safe environment and safe drinking water, access to safe and affordable family planning and basic support during pregnancy and delivery, prevention from diseases etc. Environmental security covers issues such as control of population, prevention from natural calamities, global warming and climate change. Community security covers the issue of conservation of traditions and cultures, language and commonly held values with the abolishment of ethnic discrimination, prevention of ethnic conflicts and protection of indigenous people. Political security under human security issues concerns about protection and promotion of human rights and freedom, abolishment of political detention, imprisonment and systematic ill treatment.

\section{Social Security Issues:}

Social security transforms and shapes societies in progressive ways on the base of strong political commitment and excellence in administration. Social security concerns in different states include the programs like social insurance, health insurance, old-aged pension, unemployment insurance, labor market programs or productive inclusion and others. Emerging social security issues include health and long term care, closing the coverage gap, population ageing, technological transition, higher public expectations, and employment of young workers, labor markets and digital economy, inequalities across the life course, new risks, shocks and extreme events, protection of migrant workers and so on. People wish to secure a decent standard of living, within a context of security and of freedom to express their opinion and to associate. They can achieve this not only through productive employment, savings and accumulated assets but also through social protection mechanisms. For this, the social security issues like demographic challenges such as ageing and changing family structures and many more other issues should be solved. More than half of the world's population is excluded from any type of social security protection which has been a major issue needed to be resolved.

\section{State Security Issues:}

State security is the way of safeguarding a country against any kind of conventional or modern security threats. State security may be challenged by social factors such as aggression from a neighboring country, infiltration from terrorist groups or global economic trends that compromise the state's welfare. State security is responsible for identifying potential dangers to the state like national security threat from foreign government with hostile intentions; chaos and disruption through terrorism; proliferation; cybercrime; natural disasters and epidemic diseases etc. These issues are needed to be addressed by the state in order to maintain peace and stability in the country. 


\section{Challenges of Security in Nepal}

The security aspect of Nepal has been threatened time and again by insurgencies, poverty, low quality of education, unemployment, environmental degradation, terrorism, outbreak of contagious diseases (like diarrhea, cholera and lately COVID-19) and many more factors. Security system of Nepal is challenged by numerous security threats like demands of identity politics raised by ethnic and regional groups, extremism, corruption, increasing narcotic trades, culture of violence, crime and disregard to law and order, human trafficking, politicization of government institutions and criminalization of politics, piracy, information security related problems, environmental security related challenges, crises resulted from earthquake, flood, landslide and other natural disasters. Political insecurity is an immediate result of war, violence, conflict, political suppression and human rights violation (Wagle, 2013, p.253). Mass migration of people from rural to urban areas and the situation of brain drain in Nepal has the changing pattern of trans-boundary activities that brings the various forms of security threats. Proliferation of small arms and light weapons across the open border of Nepal is seen as a major threat to the country that has postured serious challenge to overall security of the country (NCFSC, 2020).

The lack of relevant policies, political stability, politically eroded efficacies of security agencies, impunity and lack of transitional justice, natural calamities and financial irregularities are the causes for the weakened security aspects of Nepal. Security institutions are also being challenged through the spreading of secessionist idea and identity issue in different parts of the country. Nepal's existing national security architecture is inadequate for managing the country's complex challenges as two government bodies- Council of Minister and National Security Council serving notionally in national security decision making, could not function well for the formulation and implementation of the security plans and policies. Council of Ministers is meant to deal with complex security issues of the country but in practice, the ministries devote vast majority of their time in managing day-to-day operational decisions without showing an aptitude for crossministerial collaboration on strategic matters. National Security Council on the other hand, lacks a comprehensive staff element and its constitutional role is also made narrow as its mandate is to only advise the Council of Ministers on mobilization, operation and use of the Nepali Army and recommend the security policies to the Council of Ministers, Government of Nepal. There still seems the gap of integration, co-operation and collaboration among different security agencies of Nepal in the performance of security roles of the country.

\section{Border Security Concern}

Nepal is located in a geo-strategically sensitive place between two giant countries India and China. Both of these countries are competing among themselves in economic, security and global structures. They are also competing for regional security but both try to maintain a stable AsiaPacific to sustain their economic prosperities. The activities performed by both of the countries directly or indirectly affect the security functions of Nepal. As Nepal is connected to India in the Eastern, Western and Southern parts whereas to China in the Northern part. It is border security concern of Nepal certainly arises among these two countries. Transnational threats like terrorism, human trafficking, smuggling, cybercrimes, pandemics and organized crimes have made the issue of border security more complex to grapple with, thus demanding a novel common approach. The 
open and porous border of Nepal to the South with the unregulated and undocumented move of people has brought a major challenge to the integrity of national borders. The nominally regulated movement of people and goods through the border has resulted in the leakage of large sum of customs revenue of Nepal encouraging the activities of illegal import and smuggling. The proliferation of arms, ammunitions, drugs and illegal imports and exports of valuable goods across the open border has been the biggest threat to the country. Cross-border crimes are being increased in an uncontrolled way. Territorial dispute of Nepal mainly with India and occasionally with China arise in the border areas that threatens the state security. Human trafficking as a result of open boarder is seen as another security threat to Nepal. Spies of India and China are having an easy access to enter Nepal which may result in the leakage of the confidential policies of Nepal regarding foreign matters to those countries. Both of the neighboring countries try to make their influence in socio-political affairs of Nepal which may bring disharmony within the country. Even though not connected through borders, but the European Union, the USA and other few countries seek to have their impact in several matters of Nepal which would be beneficial for them.

\section{Way Forward}

At the current phase of transforming and newly evolving security issues including conventional and modern security threats along with transnational security issues; the global cooperation among states against all the security problems is very much needed. Whereas, I Nepal, the security policies should be amended as per the changing security threats and requirement of changing time. The security policies should be implemented strictly with the provision of good governance in the country. If the effective steps against security problems are not taken in Nepal and if the condition is left intact, then there might be a great threat to the sovereignty, peace and stability of the country resulting devastating consequences in coming time. Nepal should deal more vividly with new security challenges by the creation of enabling environment at the federal, provincial and local levels of the country. Favorable legal-regulatory provisions, supportive institutional arrangement, investment in capacity building programs especially in education and research, development of sound intelligence and integrating security policy with international relations, economic development and social services, maintenance of equidistant and co-operative non-aligned relation with the neighboring countries and proper monitoring of security relate activities in the country by concerned authorities would be helpful for the delivery of sound security system in the country. Corruption free society plays an important role to strengthen the national security of the country. Provision of human rights should be assured to every people of the country whereas rescue and rehabilitation to the victims of wars, conflict and natural disasters should be made prompt and effective. Nepal needs a flexible and resourced national security architecture by which it can seize opportunities created by the global security environment, deal with new challenges that cut across bureaucratic boundaries, and institutionalize the government's strengths including its notable contribution to global peace keeping operations. An efficient institutional mechanism addressing security concern of the state and its people should be formed and functioned well. 


\section{Concluding Remarks}

Security is a multidimensional concept that demands for its evolution as per the evolution of the variants of threats arising in the world. Almost all the countries across the world are facing different forms of security threats resulting from migratory movements, cyber terrorism, environmental degradation, attacks from the terrorist groups, civil wars, organized crime, pandemics, global warming, climate change, violation of human rights, ethnic, racial or religious conflicts, poverty, inequalities and many more. Issues regarding human security, national security, social security, environmental security and other different forms of security should be addressed and solved through collaborative effort of every states of the world. The situation of increasing security threats has been a greater problem for Nepal as well, as it has hampered the peace, security and stability of the country. Several forms of terrorism and crimes are recorded in Nepal as a result of weak implementation of security policies. Hence, coordinated effort of National Security Council, Nepali Army, Nepal Police, Armed Police Force, Nepal and National Investigation Department is necessary for the solution of security issues in Nepal and therefore, for the national progress. Diplomatic and balanced foreign policies with neighboring and other countries would help more to strengthen the security of the country by the protection of its sovereignty.

\section{References}

APF (Armed Police Force). (2020). Retrieved from https://www.apf.gov.np/

Barnett, J. (2001). The Meaning of Environmental Security: Ecological Politics and Policy in the New Security Era. London: Zed Books.

Bhushal, T.R. (2076 BS). Rastriya Surakshya ra Bikas (National Security and Development). Civil Service Journal. 41(1). 22-32.

Karki, Shweta. (2020). The Evolution of Security: Small States in South Asia. Retrieved from https://www.nepalfirst.org/the-evolution-of-security-small-states-in-south-asia/

Lasswell, H. (1950). National Security and Individual Freedom. New York : McGraw-Hill Book Co.

Lippmann, W. (1944). U.S. Foreign Policy. Political Science Quarterly. 129(4). 599-601.

MoD (Ministry of Defense). (2020). About Ministry. Retrieved from https://www.mod.gov.np/en/post/about-ministry

National Security Policy of Nepal, 2016

Nepal Police. (2020). Retrieved from https://www.nepalpolice.gov.np/index.php

Nepali Army. (2020). Retrieved from https://www.nepalarmy.mil.np/

NCFSC (Nepal Center For Security Governance). (2020). Security Challenges in Nepal. Retrieved from http://nepalsecgov.org/security-challenges-in-nepal/ 
Opara, U.L. (2013). Perspective: The evolving dimensions and perspectives on food security what are the implications for postharvest technology research, policy and practice?. International Journal of Postharvest Technology and Innovation, 3(3). 324-332.

Raghavan, V. (2007). Challenges to Global Security. Global Security. 60(3). 23-39

Rothschild, E. (1995). What is security?. Daedalus. 124(3). 53-98.

Singh, A.K. (2019). Human Security in Nepali Perspective. Journal of APF Command and Staff College. 2(1). 60-66.

Sperling, J. \& Kirchner, J. (1995). The Changing Definition of Security (paper). The ECSA Conference. Charleston.

The Constitution of Nepal, 2015

The Himalayan. (2020). Nepal's female soldiers break taboos to tackle COVID crisis. Retrieved from https://thehimalayantimes.com/nepal/nepals-female-soldiers-break-taboos-to-tacklecovid-crisis/

TMP (The Millennium Project). (2020). Retrieved from http://www.millennium-project.org/

Ullman, R.H. (1983). Redifining Security. International Security. 8(1). 129-153.

Upreti, B.R. (2019). Security for Enhancing Peace and Stability in Changing Context of Nepal. Journal of APF Command and Staff College. 2(1). 1-13.

Upreti, B. R. \& Vanhoutte, P. (2009). Security sector reform in Nepal: Challenges and opportunities. In Born H, Schnabel A, (eds). Security Sector Reform in Challenging Environments. Geneva: LIT Verlag, 165-187.

UN (United Nations). (2012). Resolution 66/290. Retrieved from https:/documents-ddsny.un.org/doc/UNDOC/GEN/N11/476/22/PDF/N1147622.pdf?OpenElement

Wagle, G.S. (2013). Political insecurity and armed conflict: A threat to human security. Human Security in Nepal: Concepts, Issues and Challenges. 1. 251-278. 